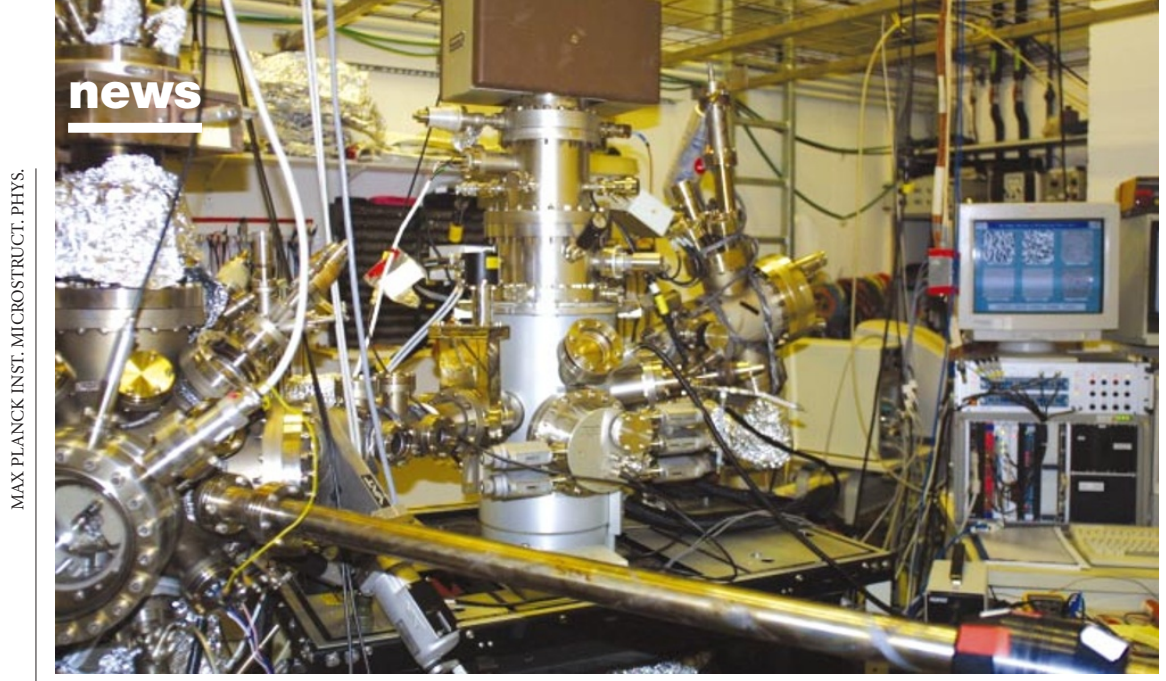

Hard times: the Max Planck Institute of Microstructure Physics must sell its surface-analysis kit.

\title{
Funding freeze leaves eastern Germany out in the cold
}

Quirin Schiermeier, Munich

Ever since German reunification in 1990, strenuous efforts have been made to beef up science in the former East Germany. The Max Planck Society (MPS) and others have injected money and talent to create institutes there of international standing. But an announcement on 30 November that funding for German science will be frozen next year has raised fears that the build-up will now falter.

The funding freeze, announced by science minister Edelgard Bulmahn at a meeting with the heads of Germany's main research organizations, is a heavy blow for the MPS, which runs 80 basic research institutes. Since reunification, the society has founded 20 institutes in eastern Germany. Now it faces a e 50-million (US\$50-million) reduction in its previously projected 2003 budget of e1.2 billion, forcing it to revise its scientific goals.

The Max Planck Institute for Biogeochemistry in Jena, south of Berlin, for example, recently reached an agreement with the Russian government over the construction of a 250-metre tower for measuring carbon dioxide fluxes over Siberian forests. But this new project may have to be dropped.

"The tower would offer unique scientific opportunities at one of the hotspots of global warming," says Ernst-Detlef Schulze, the institute's scientific director. "It would hit us hard if it were stopped."

The 'Aufbau Ost' - the campaign to build up eastern Germany since 1990 - has enabled the MPS to enter new scientific territory. Many of the generously equipped institutes are becoming internationally competitive in fields such as cell biology, genetics, evolutionary anthropology, primate research and plant biology.

But that financial largesse is now disappearing, says Jürgen Kirschner, scientific director of the Max Planck Institute of Microstructure Physics in Halle.

The institute's facility for magnetic surface analysis, for example, which cost e500,000 to build, is to be sold to a US laboratory because its operating costs are higher than expected and its maintenance support is falling.

"Running and repair costs are eating us up," says Kirschner, who has little hope that the MPS will now invest in a hoped-for new e750,000 atomic-force microscope for nanostructure analysis.

Cutting investment is one means of coping with the budgetary constraints, says Peter Gruss, the MPS president. But in the longer term, the society will only be able to maintain scientific quality by reducing the number of its research departments, he says. "We will need to close at least 20 departments, maybe even some institutes," he says. "This means a $10 \%$ reduction in our research potential."

Ten of the new institutes in the east are still without directors, partly because of the difficulties of luring scientific heavyweights to eastern Germany. Some of these positions may remain vacant, says Gruss.

Across Germany, a third of the society's 240 scientific directors will reach retirement age in the next six years. Gruss says that only 60 of the resulting 80 vacancies will be filled.

The cutbacks in the 2003 budget plans for Germany's research organizations were announced as the country faces its worst economic crisis for decades. Even so, the government's decision to renege on a pledge made before September's election of a 3\% increase in research budgets next year surprised some scientists and research administrators.

"This is a drastic turn in research policy," says Ernst-Ludwig Winnacker, president of the DFG, Germany's main university research funding agency, which will have to save millions of euros next year (see story, right).

\section{Postdoc positions axed as economic crisis takes its toll}

\section{Quirin Schiermeier, Munich}

As many as 2,000 young German scientists are set to get a nasty shock in the mail as laboratories cancel planned positions in response to a budget freeze.

After last week's announcement that research budgets will be frozen at this year's level (see left), the DFG, Germany's main university research funding agency, will have $\mathrm{E} 43$ million (US $\$ 43$ million) less to spend than it had anticipated.

The agency supports about 27,000 graduate students and postdoctoral fellows in all disciplines. It says that this number is set to fall by about $10 \%$.

"The success rate of applicants will decrease," says Ernst-Ludwig Winnacker, the DFG's president. Most disappointed will be those young researchers whose planned thesis or postdoctoral work in a collaborative project has been approved and must now be cancelled, he adds.

The Max Planck Society is not doing any better. The planned extension of International Max Planck Research Schools - an initiative aimed at improving training opportunities for PhD students - is likely to be delayed, and plans to set up a Max Planck group for stem-cell research at the University of Ulm may also be suspended.

Additionally, the continuation of the European Neuroscience Institute in Göttingen - four independent junior neurobiology groups jointly funded by the Georg August University of Göttingen and the MPS - may be at risk.

Stopping the project now would be disastrous, says Erwin Neher, who runs the Max Planck Institute for Biophysical Chemistry in Göttingen. "What's the use of complaining that Germany's brightest talent leaves the country if you cut, of all the institutes, the most attractive and competitive ones?"

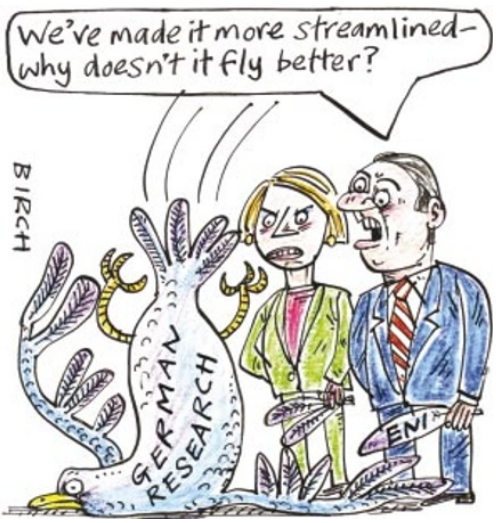

